\title{
The first major incision of the Swiss Deckenschotter landscape
}

\author{
Naki Akçar • Susan Ivy-Ochs • Vasily Alfimov • Anne Claude • \\ Hans R. Graf • Andreas Dehnert - Peter W. Kubik • Meinert Rahn • \\ Joachim Kuhlemann · Christian Schlüchter
}

Received: 20 June 2014 / Accepted: 3 November 2014/Published online: 20 November 2014

(C) Swiss Geological Society 2014

\begin{abstract}
The Swiss Deckenschotter ("cover gravels") is the oldest Quaternary units in the northern Swiss Alpine Foreland. They are a succession of glaciofluvial gravel layers intercalated with glacial and/or overbank deposits. This lithostratigraphic sequence is called Deckenschotter because it "covers" Molasse or Mesozoic bedrock and forms mesa-type hill-tops. Deckenschotter occurs both within and beyond the extent of the Last Glacial Maximum glaciers. The Swiss Deckenschotter consist of two subunits: Höhere (Higher) and Tiefere (Lower) Deckenschotter. Although the Höhere Deckenschotter sub-unit (HDS) is topographically higher than the Tiefere Deckenschotter, it is older. The only available age for the Swiss Deckenschotter is $2.5-1.8 \mathrm{Ma}$ based on mammal remains found in HDS at the Irchel site. In this study, we present an exposure age for the topographically lowest HDS, calculated from a cosmogenic ${ }^{10} \mathrm{Be}$ depth-profile. Our results show that the first phase of the Deckenschotter glaciations in the Swiss Alps terminated at least $1,020_{-120}^{+80} \mathrm{ka}$ ago, which is indicated by a significant fluvial incision. This line of evidence seems to be close to synchronous with the beginning of the
\end{abstract}

N. Akçar $(\bowtie) \cdot$ A. Claude $\cdot$ C. Schlüchter

Institute of Geological Sciences, University of Bern,

Baltzerstrasse 1-3, 3012 Bern, Switzerland

e-mail: akcar@geo.unibe.ch

S. Ivy-Ochs · V. Alfimov · P. W. Kubik

Labortory of Ion Beam Physics (LIP), ETH Zurich,

Schafmattstrasse 20, 8093 Zurich, Switzerland

H. R. Graf

Dorfstrasse 40, 8014 Gächlingen, Switzerland

A. Dehnert · M. Rahn · J. Kuhlemann

Swiss Federal Nuclear Safety Inspectorate ENSI,

Industriestrasse 19, 5200 Brugg, Switzerland
Mid-Pleistocene Revolution, when the frequency of the glacial-interglacial cyclicity changed from 41 to $100 \mathrm{ka}$ and the amplitude from low to high, between marine isotope stages 23 and 22 .

Keywords Switzerland - Quaternary geology · Cosmogenic exposure dating $\cdot{ }^{10} \mathrm{Be}$ depth profile . Late Glacial Maximum · Mid-Pleistocene Revolution

\section{Introduction}

Alpine glaciers advanced and reached the northern Alpine Foreland at least 15 times during the Quaternary (Schlüchter 1988). These advances are recognized within four distinct units, which are differentiated by their topographical position and morphostratigraphy. The topographically higher units are older than the lower ones. These are, from the oldest to youngest, Höhere Deckenschotter, Tiefere Deckenschotter, Hochterrasse (HTHigher Terrace) and Niederterrasse (NT-Lower Terrace; Fig. 1). For a long time, the Quaternary stratigraphy of the northern Alpine Foreland had been correlated to that of southern Germany where the four units are attributed to the Günz, Mindel, Riss and Würm glaciations of Penck and Brückner (1909). According to this correlation, HDS was correlated with Günz, TDS with Mindel, HT with Riss and NT with Würm, respectively (e.g., Ellwanger et al. 2011). This continued until Schlüchter (1988) presented a new stratigraphy based on the detailed field studies.

HDS and TDS are the oldest Quaternary units in the northern Swiss Alpine Foreland and are called collectively the Swiss Deckenschotter. They are well preserved beyond the extent of the Last Glacial Maximum (LGM) ice between Lägern to the south and the river Rhine to the 


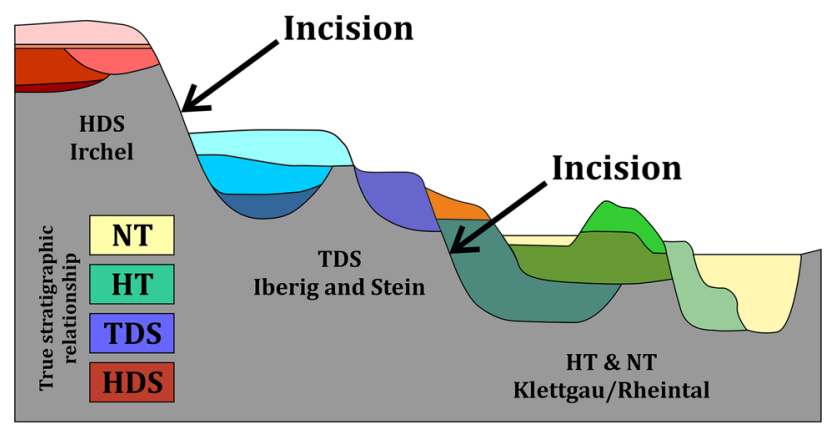

TDS: Iberig and Stein

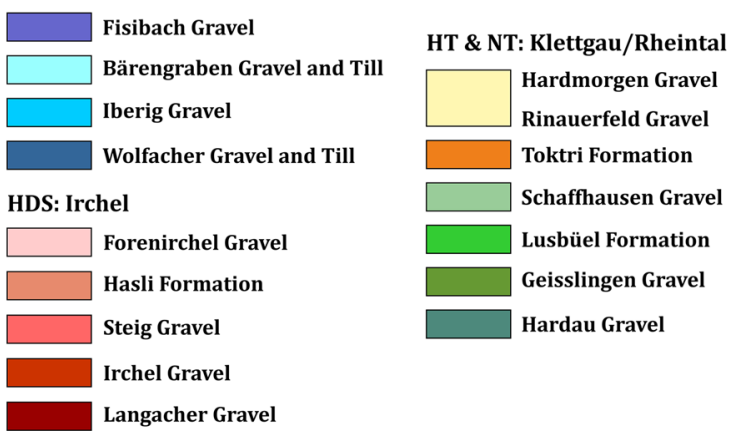

Fig. 1 Schematic stratigraphy of the Quaternary deposits of the northern Alpine Foreland (after Graf and Müller 1999). The unit sampled at Mandach is according to present knowledge the youngest of the HDS units, and may be correlative to the uppermost beds of the HDS at Irchel

north (Fig. 2). While the same nomenclature has been applied to the "Deckenschotter" of Penck and Brückner (1909) in southern Germany, the precise correlation between these deposits has not been yet been unequivocally established. They are a succession of several glaciofluvial gravel layers intercalated with glacial and/or overbank sediments deposited in valleys and they also contain fluvial deposits of warm periods. They were deposited in broad channels and, therefore, they do not represent ice-margin sediments deposited on the hill-tops during the Pleistocene (Graf 1993). Swiss Deckenschotter deposits are separated from the younger units by a remarkable phase of incision (Graf 1993, 2009). Similarly, HDS and TDS are separated from each other by an intervening phase of incision. The genetic relationship of HDS to foreland glaciations are mainly given by the following field evidence: interbedded tills at some locations, fartravelled erratic boulders for example at the Irchel (IRC) site, precipitated glacier milk as a secondary cement, sedimentary facies of a braded-river system with subangular to subrounded clasts (Graf 1993 and references therein).

The timing of events in this complicated terrestrial stratigraphy of the Quaternary in the northern Alpine Foreland is not yet completely established. The chronology of the Late Quaternary glaciations is relatively better established compared to the older ones (e.g., Ivy-Ochs et al. 2008; Preusser et al. 2011; and references therein). The timing of Deckenschotter glaciations is still completely unknown, although some attempts have been made in the past (e.g., Bolliger et al. 1996). The reconstruction of the Deckenschotter chronology is of scientific and social importance. The scientific aspect is the timing of the onset of glaciations in the Alps; knowing its age is critical because it has direct impact on our understanding of Quaternary paleoclimate and landscape dynamics. The social aspect is the long-term safety of the nuclear waste in deep geological repositories, suggested to be established in northern Switzerland.

Following the onset of glaciations in the northern hemisphere at around $2.7 \mathrm{Ma}$, oscillation of the ice sheets (i.e. glacial-interglacial cycles) delineated the extent of glaciation on a hemispherical scale (Maslin and Ridgwell 2005). The beginning of glacial-interglacial cycles and their records in the Alpine Foreland indicate that glaciers advanced from the high Alpine valleys down to the foreland, giving birth to the Alpine ice sheets. The building of ice sheets in the northern hemisphere resulted in an environmental change, completely new and not recorded before (Maslin and Ridgwell 2005). These continental scale ice masses were coupled with atmospheric circulation patterns, which had a direct impact on climate change. Therefore, the onset of glaciations in the northern hemisphere at the end of the Neogene/beginning of the Quaternary is of crucial importance and a direct input for paleoclimate models.

With the growing world's population and expanding industrialization, the demand on energy increases. Nuclear energy has been produced for more than half-century, and requires higher levels of safety compared to the other energy sources. This is not only valid for energy production, i.e. nuclear power plants, but also for the disposal of nuclear waste material. Based on the Swiss Nuclear Energy Act, Swiss authorities have decided to build deep geological repositories for permanent and safe of nuclear waste (www.nagra.ch). Due to the long irradiation time of the waste disposal, these deep repositories are required to survive at least $1 \mathrm{Ma}$. Therefore, the geological history of the Alpine Foreland during the last $1 \mathrm{Ma}$ must be well understood in order to plan the $1 \mathrm{Ma}$ residence of nuclear waste in these repositories. Such a long time of residence requires the strata overlying the repository should not be removed by fluvial or glacial erosion. Therefore, the selected repository sites in Switzerland are mostly beyond the extent of LGM and the denudation rates for the entire Quaternary should be constructed for the long-term safety of the disposal site in order to estimate probable and possible environmental change during the next $1 \mathrm{Ma}$.

Bearing the scientific and social needs for the timing of Deckenschotter glaciations in mind, and considering the 


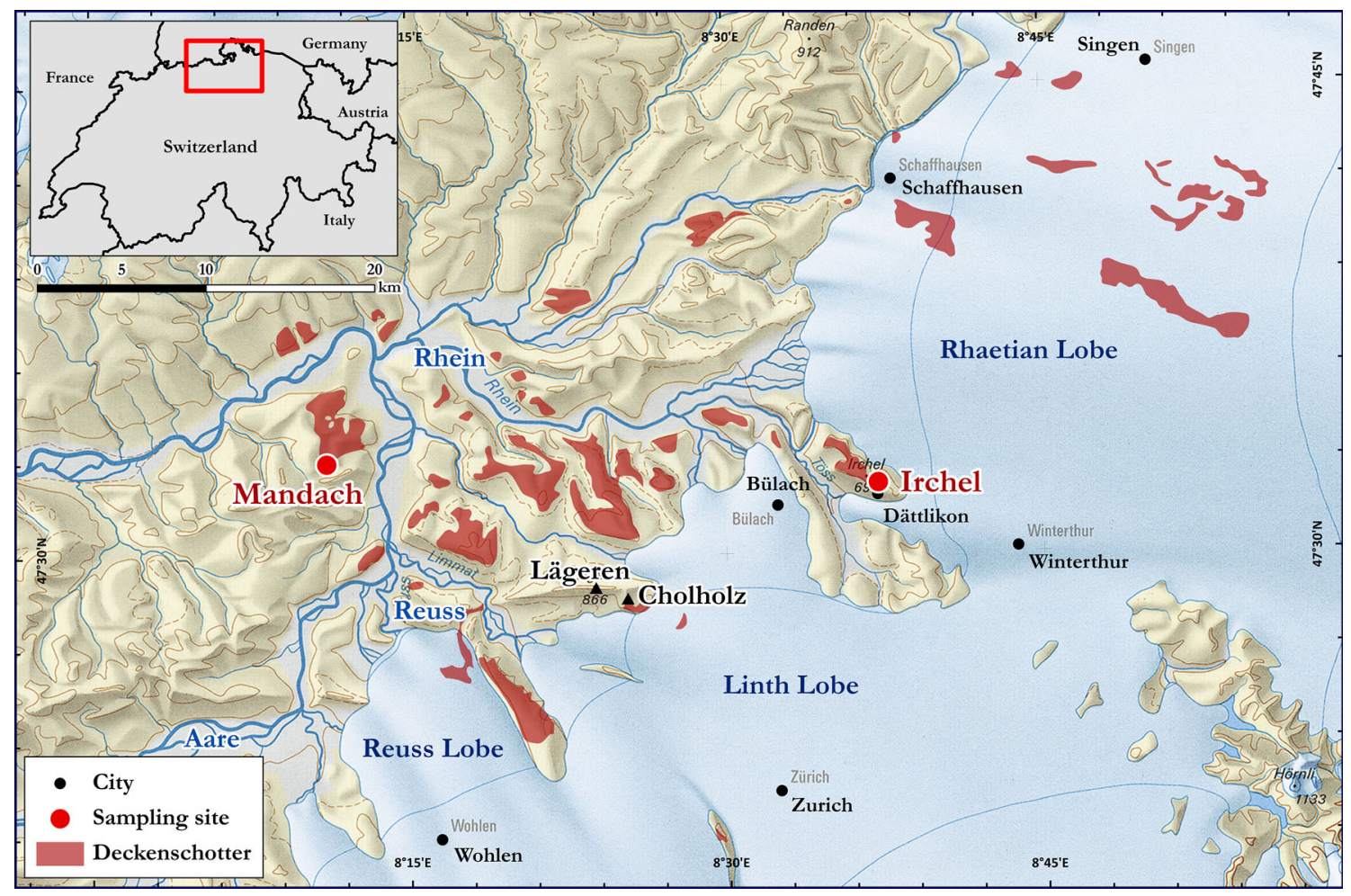

Fig. 2 Extension of the Reuss, Lindth and Rhaetian Lobes during the Last Glacial Maximum (from Bini et al. 2009), locations showing the location of the Mandach and Irchel sites and the distribution of Swiss
Deckenschotter in northern Switzerland. CFederal Office of Topography, swisstopo, $\mathrm{CH}-3084$ Wabern

Boppelsen, canton Zurich (Jayet 1949; Fig. 2). He concluded that it is not possible to attribute this fauna to a specific interglacial, and he proposed two interpretations: continuous or discontinuous succession. The continuous succession would mean that the Upper Pleistocene glacial deposits are overlain by post-glacial to Holocene units. In contrast, the discontinuous succession would imply that Lower Quaternary fluvial or glaciofluvial deposits unconformably are overlain by Upper Pleistocene deposits, which bear the molluscan fauna. Graf (1993) studied the same site and concluded that the upper part of the section, which was interpreted as Upper Pleistocene deposits by Jayet (1949), may safely be attributed to Deckenschotter. As the molluscan fauna is not post-glacial, it can only be older (Graf 1993). In the 1990s, mammal remains were found in the HDS at the IRC site (Fig. 2). An age of 2.6-1.8 Ma, i.e. mammalian zone 17 (MN17), was determined (Bolliger et al. 1996), which was the only available age for the Swiss Deckenschotter until the present study. Besides the paleontological evidence, Graf (1993) analyzed paleomagnetism of the Swiss Deckenschotter. He concluded that deposition of HDS probably occurred during the Matayuma chron.
The first attempt to date the Swiss Deckenschotter was the paleontological analysis of the molluscan fauna abundances in the upper part of the around $11.5 \mathrm{~m}$ long section of the HDS outcrop at Cholholz am Wildstock, northeast of 


\section{Sampling sites}

\subsection{The Irchel site}

At IRC the HDS is unconformably overlying Molasse bedrock. This is the typical bedrock/HDS configuration in the northern Alpine Foreland (Gutzwiller 1894; Graf 1993). The HDS sequence consists of the following five sub-units, from bottom to top (oldest to youngest): Langacher Gravel, IRC Gravel, Steig Gravel, Hasli Formation and Forenirchel Gravel (Fig. 1; Graf 1993). The Langacher Gravel is characterized by a caliche nodule-bearing paleosol layer in its upper parts and is the oldest Quaternary unit at IRC. The IRC and Steig Gravel sub-units are glaciofluvial deposits, which are overlain by the Hasli Formation. The Hasli Formation is composed of overbank and channel fill sediments deposited by a meandering river system. The stratigraphically youngest Quaternary unit is the glaciofluvial sediments of the Forenrichel Gravel (Graf 2000). Bolliger et al. (1996) identified gastropods, plants and remains of small mammals (arvicolids) in the sediments. Their analysis and interpretation yielded MN17 (2.6-1.8 Ma) for the Hasli Formation. In an abandoned gravel pit near Steig at IRC, northwest of Dättlikon (canton Zurich), four samples (IRC-1, -2, -3 and -4) were collected from the Steig Gravel for exposure dating with a cosmogenic ${ }^{10} \mathrm{Be}$ depth-profile (Figs. 2, 3). At this location, the top surface of the depth-profile is at an altitude of $670 \mathrm{~m}$ a.s.l. (Table 1).

\subsection{The Mandach site}

The HDS deposits in an abandoned gravel pit (Buech III in Graf 1993), ca. 850 m north of MND, are characterized by an at least $20 \mathrm{~m}$ thick sequence of irregularly cemented gravel. This sequence is crudely bedded, composed of mainly clast-supported gravels with average size of $5-10 \mathrm{~cm}$ ranging up to ca. $20 \mathrm{~cm}$. The gravels are subangular to subrounded in shape. The top of the deposit is located at $507 \mathrm{~m}$ a.s.l. From the gravels in the upper part of this HDS sequence, four levels were sampled (MND-1, -2, -3 and -4) for depth-profile dating (Figs. 2, 4; Table 1). The gravel sequence at MND is considered to be the youngest HDS unit (Graf 1993).

\section{Depth-profile dating}

Cosmogenic ${ }^{10} \mathrm{Be}$ and ${ }^{26} \mathrm{Al}$ can be used to determine the time elapsed since a sediment layer was deposited. For this, either the radioactive decay or accumulation of these nuclides can be used. In the case of radioactive decay, the burial time is determined by the ${ }^{26} \mathrm{Al}$ versus ${ }^{10} \mathrm{Be}$ ratio, which decreases with time as the half-life of ${ }^{26} \mathrm{Al}$ is shorter than that of ${ }^{10} \mathrm{Be}$, when the pre-burial and post-burial concentrations are known or estimated (e.g., Granger and Muzikar 2001). In a classical burial dating application, pre-burial nuclide accumulation is assumed to be saturated and deeply buried sediments (e.g., cave sediments) are sampled, where

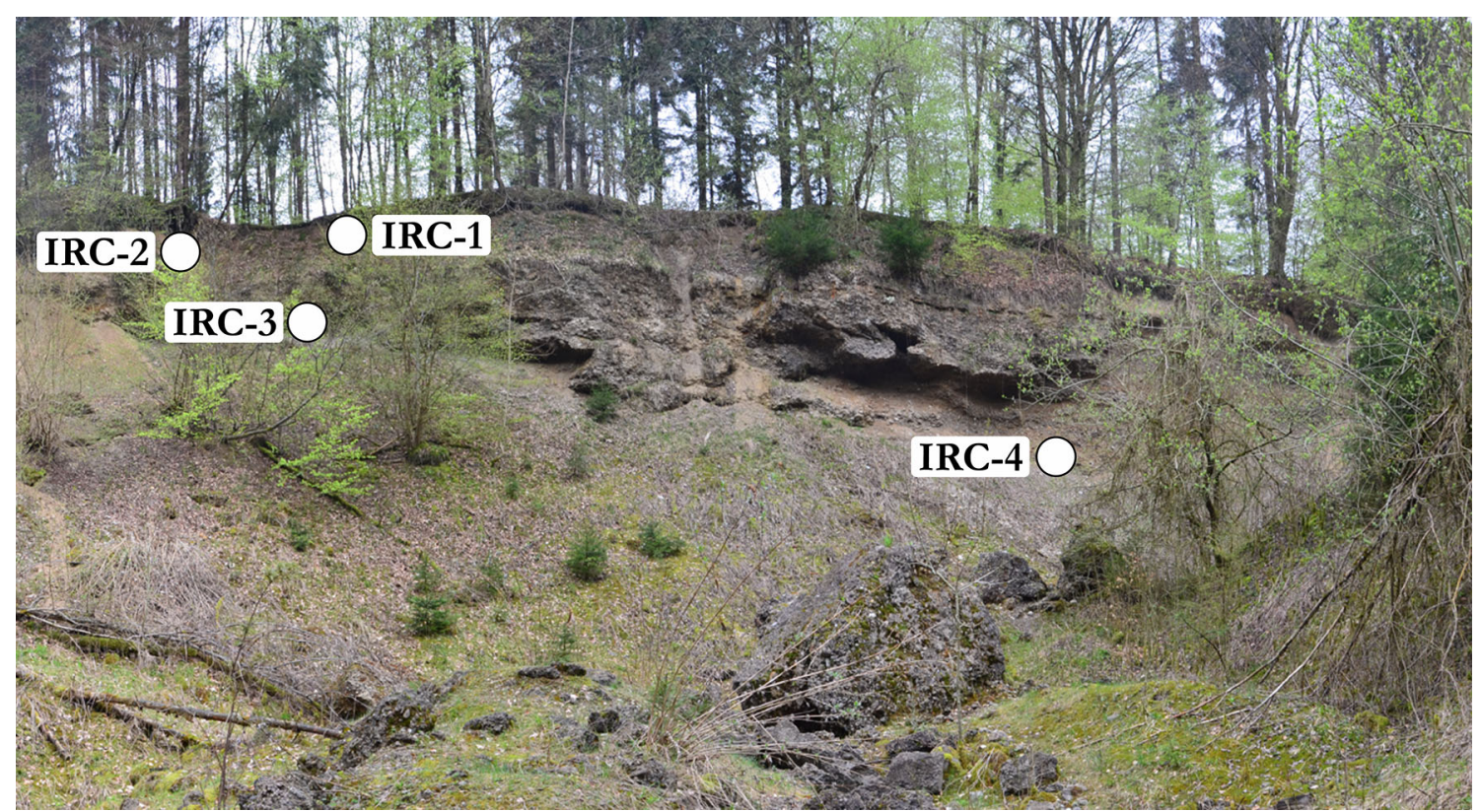

Fig. 3 Panoramic field photograph showing the locations of the IRC samples at the Irchel site 
Table 1 Description and cosmogenic ${ }^{10} \mathrm{Be}$ data of the Deckenschotter samples

\begin{tabular}{|c|c|c|c|c|c|c|c|c|c|}
\hline $\begin{array}{l}\text { Sample } \\
\text { name }\end{array}$ & $\begin{array}{l}\text { Altitude } \\
\text { (m a.s.l.) }\end{array}$ & $\begin{array}{l}\text { Latitude }\left({ }^{\circ} \mathrm{N}\right) \\
\text { (DD.DD) }\end{array}$ & $\begin{array}{l}\text { Longitude }\left({ }^{\circ} \mathrm{E}\right) \\
\text { (DD.DD) }\end{array}$ & $\begin{array}{l}\text { Sample } \\
\text { depth }(\mathrm{cm})\end{array}$ & $\begin{array}{l}\text { Quartz } \\
\text { dissolved (g) }\end{array}$ & $\begin{array}{l}{ }^{9} \text { Be spike } \\
(\mathrm{mg})\end{array}$ & $\begin{array}{l}{ }^{10} \mathrm{Be} /{ }^{9} \mathrm{Be} \\
\left(\times 10^{-14}\right)\end{array}$ & $\begin{array}{l}\text { Error } \\
\text { in }{ }^{10} \mathrm{Be} /{ }^{9} \mathrm{Be}(\%)\end{array}$ & $\begin{array}{l}{ }^{10} \mathrm{Be} \\
\text { concentration } \\
\left(10^{4} \text { at } / \mathrm{g}\right)\end{array}$ \\
\hline MND-1 & 507 & 47.5542 & 8.1873 & 100 & 49.4130 & 0.1388 & 14.46 & 10.4 & $2.66 \pm 0.28$ \\
\hline MND-2 & & & & 200 & 55.4093 & 0.1396 & 9.74 & 10.2 & $1.59 \pm 0.17$ \\
\hline MND-3 & & & & 400 & 67.1225 & 0.1389 & 7.49 & 11.8 & $0.99 \pm 0.12$ \\
\hline MND-4 & & & & 800 & 50.9469 & 0.1382 & 7.2 & 12.0 & $1.25 \pm 0.16$ \\
\hline IRC-1 & 670 & 47.5357 & 8.6148 & 50 & 82.6329 & 0.1484 & 277.82 & 3.0 & $33.30 \pm 1.00$ \\
\hline IRC-2 & & & & 150 & 69.1194 & 0.1486 & 22.55 & 5.1 & $3.19 \pm 0.17$ \\
\hline IRC-3 & & & & 400 & n.a. & & & & \\
\hline IRC-4 & & & & 800 & 68.0309 & 0.1435 & 10.73 & 7.9 & $1.47 \pm 0.12$ \\
\hline
\end{tabular}

Reported blank ratio and concentration are referenced to S2007N (Kubik and Christl 2010). AMS measurement errors are at $1 \sigma$ level, including the statistical (counting) error and the error due to normalization of standards and blanks. The error weighted average ${ }^{10} \mathrm{Be} /{ }^{9} \mathrm{Be}$ full process blank ratio is $(3.13 \pm 0.34) \times 10^{-15}$. Exposure ages are calculated with the CRONUS-Earth exposure age calculator (http://hess.ess.washington.edu/ math/; v. 2.2; Balco et al. 2008 and update from v. 2.1 to v. 2.2 published by Balco in October 2009 using preliminary CRONUS/UW production rate calibration data set) and time dependent (Lal 1991; Stone2000) scaling model. The uncertainties reported in parentheses also include the production rate error. A half-live of $1.39 \mathrm{Ma}$ for ${ }^{10} \mathrm{Be}$ (Korschinek et al. 2010; Chmeleff et al. 2010) is used for the age calculations

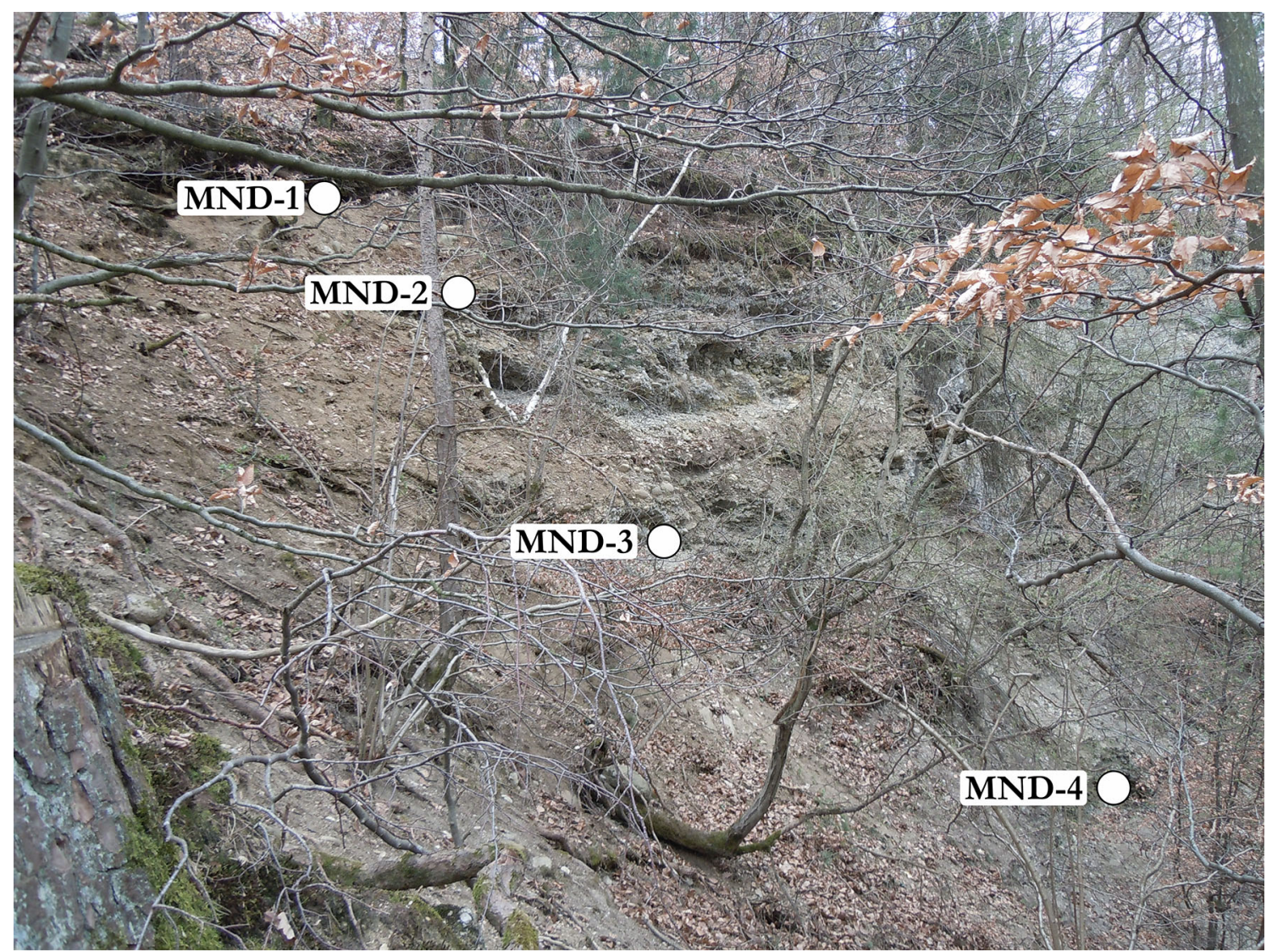

Fig. 4 Field photograph showing the locations of the MND samples at the Mandach site

the post-burial accumulation is negligible. In the recently introduced isochron-burial dating, it is assumed that in a suite of samples from the same timeline (geologic unit) post-burial history is the same. They should have different inherited nuclide concentrations acquired during different pre-burial exposure histories (Balco and Rovey 2008; 
Erlanger et al. 2012). In the case of accumulation, the variation of cosmogenic nuclide concentration with depth can be used to exposure date the accumulated sediment layer. This so called depth profile can be modeled with a Monte Carlo simulator recently developed by Hidy et al. (2010), which generates depth profiles based on exposure age, erosion rate and inheritance.

Burial dating of sediments has already been applied on the Alpine Foreland. Häuselmann et al. (2007a) attempted to burial date Deckenschotter (sensu Penck and Brückner 1909) at the original type locality in Bavaria, southern Germany. The analysis of cosmogenic ${ }^{10} \mathrm{Be}$ and ${ }^{26} \mathrm{Al}$ yielded burial ages of $0.68_{-0.24}^{+0.23}$ Ma for TDS at Bad Grönenbach and $2.35_{-0.88}^{+1.08} \mathrm{Ma}$ for HDS at Böhener Feld. Later, Dehnert et al. (2010) applied burial dating to the proglacial sediments of the Höhenschotter (HT) at two sites (Landiswil and Schöfftland) in the Alpine Foreland, attributed to an extensive middle Pleistocene glaciation. The analysis of cosmogenic ${ }^{10} \mathrm{Be}$ and ${ }^{26} \mathrm{Al}$ may indicate a maximum burial age of around $400 \mathrm{ka}$ for this unit. The main obstacle for the calculation of statistically reasonable burial ages was the high analytical uncertainties (up to $20 \%$ ) because of low nuclide concentrations. Despite the high analytical uncertainties, these studies still provide valuable information on the dating of older glaciations in the Alpine Foreland. In order to reduce analytical uncertainty, we recently improved our laboratory protocol especially for measuring low concentrations of ${ }^{10} \mathrm{Be}$ (Akçar et al. 2012).

Collected samples were processed at the Surface Exposure Laboratory of the University of Bern. The quartz in the samples was extracted and purified (e.g., Akçar 2006). Purified samples were prepared for the AMS measurements at the ETH tandem facility in Zurich (Kubik and Christl 2010) following the laboratory protocol defined in Akçar et al. (2012). The weighted average ${ }^{10} \mathrm{Be} /{ }^{9} \mathrm{Be}$ ratio of $(3.13 \pm 0.34) \times 10^{-15}$ was used for full process blank correction. Cosmogenic ${ }^{10} \mathrm{Be}$ data for the samples are given in Table 1.

${ }^{10} \mathrm{Be}$ exposure ages based on the depth profile were calculated with the MathLab ${ }^{\circledR}$ version of the Monte Carlo simulator developed by Hidy et al. (2010; available online at http://geochronology.earthsciences.dal.ca/downloadsmodels.html). The input parameters for the simulations are presented in Table 2 . The production rate was locally scaled according to the Lal (1991), Stone (2000) scheme using a production rate due to spallation (at sea level, high latitude) of $3.93 \pm 0.19 \mathrm{at} / \mathrm{g} / \mathrm{a}$ (NENA production rate calibration set; Balco et al. 2009; CRONUS calculator update from v. 2.1 to v. 2.2 published by Balco in October 2013 after Balco et al. 2008). The muon production was fit to a depth of 10 meters. Based on Dunne et al. (1999), an exponential attenuation length of $160 \pm 5 \mathrm{~g} \mathrm{~cm}^{-2}$ was considered for the shielding of the sample depth. We
Table 2 Input parameters for the Monte Carlo simulator in Matlab (Hidy et al. 2010)

\begin{tabular}{|c|c|}
\hline Parameter & Value \\
\hline Latitude $\left({ }^{\circ}\right)$ & 47.554 \\
\hline Longitude $\left(^{\circ}\right)$ & 8.187 \\
\hline Altitude (m) & 507 \\
\hline Strike $\left(^{\circ}\right)$ & 0 \\
\hline $\operatorname{Dip}\left({ }^{\circ}\right)$ & 0 \\
\hline Shielding correction factor & 1 \\
\hline Cover correction factor & 1 \\
\hline Uncertainty of ${ }^{10} \mathrm{Be}$ half-life (\%) & 1 \\
\hline Local spallogenic production rate (at/g/a) & 5.88 \\
\hline Error in local spallogenic production rate (at/g/a) & \pm 0.19 \\
\hline Depth of muon fit (m) & 10 \\
\hline Error in total production rate $(\%)$ & 5 \\
\hline Density $(\mathrm{g} / \mathrm{cm})$ & $1.8-2.4$ \\
\hline$\chi^{2}$ value & 8 \\
\hline Number of profiles & 100,000 \\
\hline Age (a) & $50,000-150,000$ \\
\hline Erosion rate $(\mathrm{cm} / \mathrm{ka})$ & $10-22$ \\
\hline Total erosion threshold $(\mathrm{cm})$ & $12,500-20,000$ \\
\hline Inheritance (at/g) & $3,000-10,000$ \\
\hline Attenuation length $\left(\mathrm{g} / \mathrm{cm}^{2}\right)$ & $160 \pm 5$ \\
\hline
\end{tabular}

A half-live of $1.387 \pm 0.012 \mathrm{Ma}$ for ${ }^{10} \mathrm{Be}$ (Korschinek et al. 2010; Chmeleff et al. 2010) is considered for the calculations. Local spallogenic production rate is calculated with the CRONUS-Earth exposure age calculator (http://hess.ess.washington.edu/math/; v. 2.2; Balco et al. 2008 and update from v. 2.1 to v. 2.2 published by Balco in October 2009) and constant production rate (Lal 1991; Stone 2000) scaling model using the NENA (Balco et al. 2009) production rate calibration dataset

assumed no effect of topographic shielding and cover (e.g., snow); therefore, we used a default value of 1 as input for these factors. Calculated local spallogenic and muonic production rates for the MND site are 5.88 and 0.21 at/g/a, and those for the IRC site are 6.87 and $0.23 \mathrm{at} / \mathrm{g} / \mathrm{a}$. We estimated a density of between 1.8 and $2.4 \mathrm{~g} / \mathrm{cm}^{3}$ along our depth profiles. ${ }^{10} \mathrm{Be}$ half-live used for the calculations is 1.387 Ma (Korschinek et al. 2010; Chmeleff et al. 2010) with $1 \%$ uncertainty. For the Monte Carlo simulation, we supposed $1-\sigma$ uncertainty level for all input parameters. In order to model the variation of ${ }^{10} \mathrm{Be}$ concentrations of MND samples, we ran the code applying a $\chi^{2}$ cutoff value of $<8$ for 100,000 profiles (Table 2).

\section{Results}

\subsection{Irchel}

The amount of quartz dissolved and ${ }^{9} \mathrm{Be}$ spike, the measured ${ }^{10} \mathrm{Be} /{ }^{9} \mathrm{Be}$ ratio and its uncertainty, and the ${ }^{10} \mathrm{Be}$ 
concentration are presented in Table 1. The purification of the sample IRC-3 did not yield enough quartz for the analysis. The AMS analysis of the other samples yielded ${ }^{10} \mathrm{Be}$ concentrations ranging from $(0.99 \pm 0.12) \times 10^{4}$ to $(3.19 \pm 0.17) \times 10^{4} \mathrm{at} / \mathrm{g}$, except for IRC-1 which has an around ten times higher concentration $([33.30 \pm 1.00] \times$ $10^{4} \mathrm{at} / \mathrm{g}$ ) compared to the highest concentration among the other samples (Table 1). ${ }^{10} \mathrm{Be}$ concentrations with $1-\sigma$ uncertainties from the MND and IRCsites decrease with increasing depth (Figs. 5, 6).

\subsection{Mandach}

The Monte Carlo simulation (Hidy et al. 2010) for the MND samples generates a modal age of $1,020_{-120}^{+80} \mathrm{ka}$ for a modal erosion rate of $15.86_{-4.48}^{+5.94} \mathrm{~cm} / \mathrm{ka}$ and inheritance of $6,100_{-2700}^{+3,900}$ at/g (Table 3). In order to allow the simulator to calculate an age, the erosion rate has to be considered. For instance in this case, $15.86_{-4.48}^{+5.94} \mathrm{~cm} / \mathrm{ka}$ is not a calculated erosion rate, it is a modal input parameter adjusted within a range of values. Therefore it cannot be used as a quantitative value for erosion (Table 3; Hidy et al. 2010). This reasoning is also true for inheritance and the value of $6,100_{-2700}^{+3,900}$ at/g is a modal input parameter as well (Table 3). As modal values are close to mean and median values, we report errors in modal values based on the minimum and maximum values produced by the simulation. An exposure age of $922.5 \mathrm{ka}$ constrained with an erosion rate of $14.83 \mathrm{~cm} / \mathrm{ka}$ and inheritance of $6,700 \mathrm{at} / \mathrm{g}$ generated the lowest $\chi^{2}$ value for the best fit of our

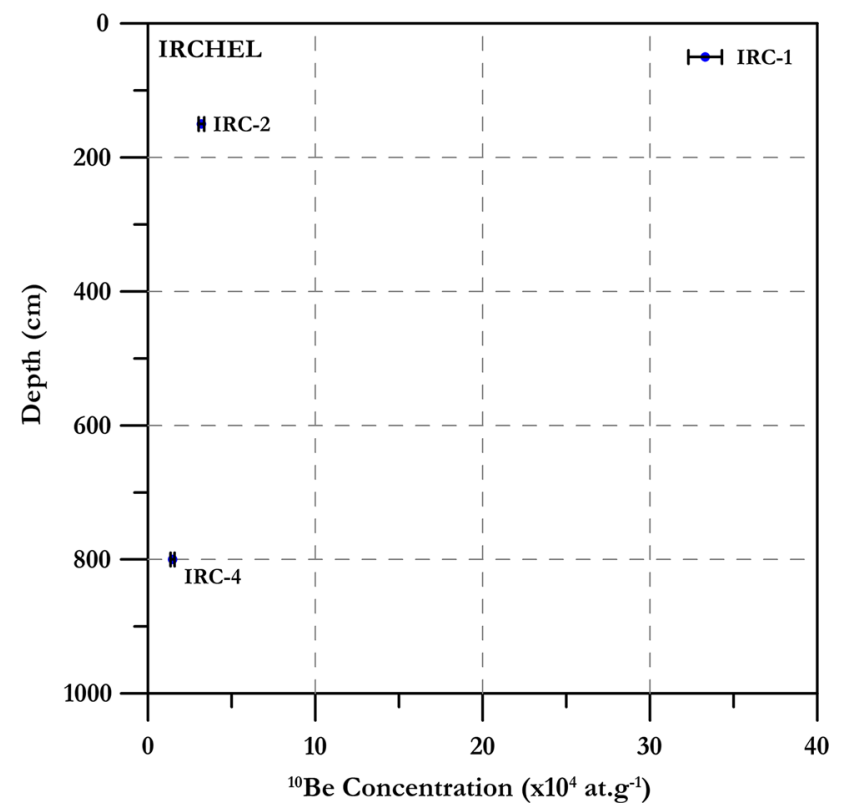

Fig. $5{ }^{10} \mathrm{Be}$ concentrations with $1-\sigma$ uncertainties of the IRC samples plotted against depth

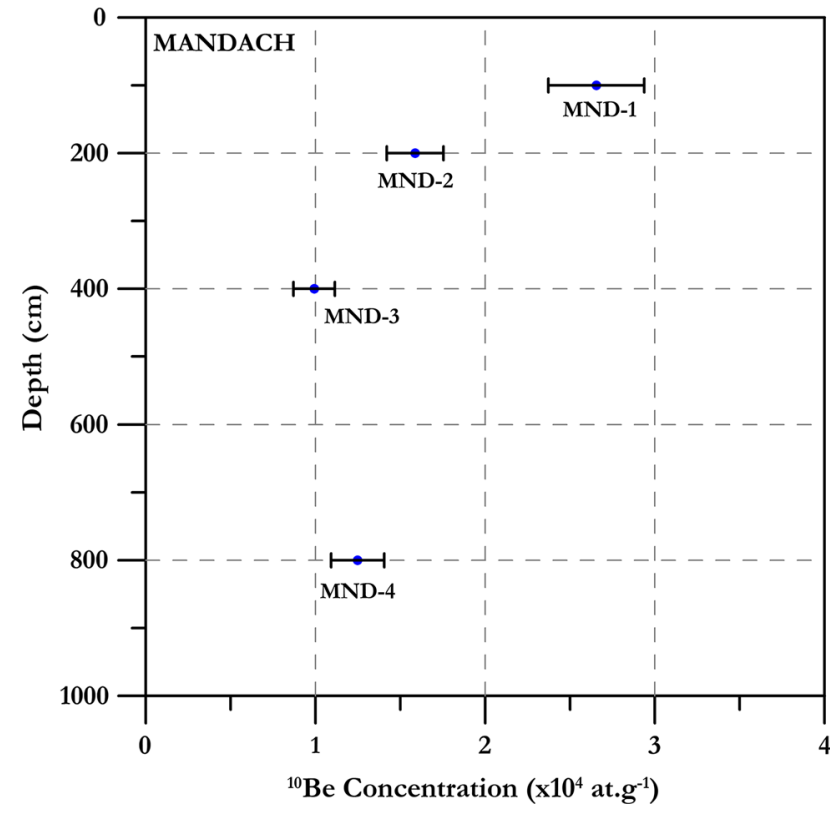

Fig. $6{ }^{10} \mathrm{Be}$ concentrations with $1-\sigma$ uncertainties of the MND samples plotted against depth

Table 3 Results of the Monte Carlo simulations with Matlab for the 4 Mandach samples

\begin{tabular}{lrll}
\hline & Age $(\mathrm{ka})$ & $\begin{array}{l}\text { Inheritance } \\
\left(10^{4} \text { atoms } / \mathrm{g}\right)\end{array}$ & $\begin{array}{l}\text { Erosion rate } \\
(\mathrm{cm} / \mathrm{ka})\end{array}$ \\
\hline Mean & $1,005.5$ & 0.62 & 16.22 \\
Median & $1,005.9$ & 0.62 & 16.19 \\
Mode & $\mathbf{1 , 0 2 1 . 2}$ & $\mathbf{0 . 6 1}$ & $\mathbf{1 5 . 8 6}$ \\
Minimum $\chi^{2}$ & 922.5 & 0.67 & 14.83 \\
Maximum & $1,100.0$ & 1.00 & 21.80 \\
Minimum & 900.0 & 0.34 & 11.38 \\
\hline
\end{tabular}

Total number of simulated profiles is 100,000 . For the minimum and maximum values $3-\sigma$ confidence level is applied. Please note that erosion rate statistics cannot be used for reporting a value for erosion rate (Hidy et al. 2010)

modeling (Fig. 7). We were not able to run the code for the IRC samples, since at least four data points are required for a realistic simulation (Hidy et al. 2010) and we had only three. In addition, the high ${ }^{10} \mathrm{Be}$ concentration of sample IRC-1 compared with IRC-2 and IRC-4 hinders the simulation with three data points for a reasonable approximation.

\section{Discussion}

The beginning of glacial-interglacial cycles at around 2.7 Ma in northern hemisphere (Maslin and Ridgwell 2005) indicates a new era of landscape change on a hemispherical scale (cf. Kuhlemann and Rahn 2013). This 


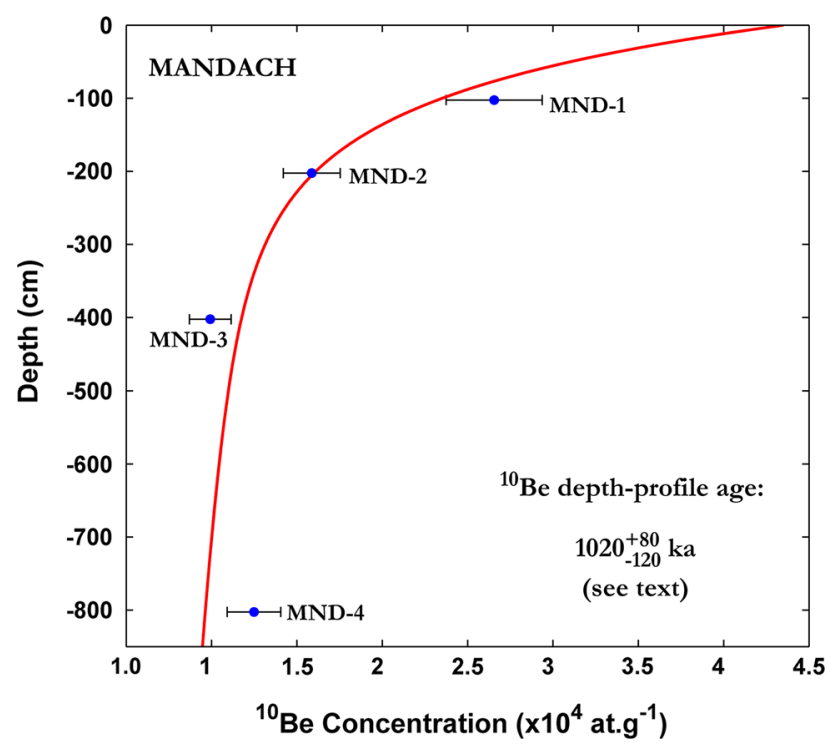

Fig. 7 Best fit of the modeled ${ }^{10} \mathrm{Be}$ concentrations of the samples from Mandach changing with depth for lowest $\chi^{2}$ value (red line). Blue dots indicate the measured ${ }^{10} \mathrm{Be}$ concentrations and horizontal dashes the $2-\sigma$ uncertainties, respectively

era was dominated by the oscillating ice sheets. Although, with our results, we cannot answer the question of synchrony of the onset of Alpine glaciation with respect to the global evidence, the Swiss Deckenschotter sediments are a geoarchive of this new era and represent the transition phase to continental scale ice sheet build-up. Similarly, this transition is documented by the North American Early Pleistocene glaciations, when there were eastern and western ice sheets, separated by 2,000 km from each other (Barendregt and Irving 1998). In contrast, Middle and Late Pleistocene glaciations produced one ice sheet from the Atlantic to Pacific oceans like the Laurentide Ice Sheet. In the North Pacific, Kent et al. (1971) identified at least 11 increased ice-rafting periods during the last $1.2 \mathrm{Ma}$, and four between 1.2 and $2.5 \mathrm{Ma}$. In the middle of the North Atlantic, ice-rafted debris was recorded as early as $2.72 \mathrm{Ma}$ (Bailey et al. 2013). However, ice draining from the Scandinavian Ice Sheet was channelized and deposited till for the first time in the Norwegian Channel at around 1.1 Ma (Sejrup et al. 2003).

The timing of Deckenschotter glaciations and the intervening and subsequent incision phases merits special importance for our understanding of Quaternary landscape change in the northern Alpine Foreland. Especially the quantification of the amount of time hidden in the incision periods between the times of accumulation is essential for assessing the long-term safety of the deep geological repositories over the long time range. Although our results from the HDS did not yield sufficient data for simulation, we suggest that the HDS at IRC is older than the HDS at
MND based on the ${ }^{10} \mathrm{Be}$ concentrations (Figs. 5, 6; Table 1). This conclusion is in accordance with the difference in elevation of these sites, IRC is ca. $160 \mathrm{~m}$ higher than the MND site. We do not consider the IRC site for in the discussion below. Nevertheless, our results are encouraging and this site will be resampled.

As mentioned above, Deckenschotter in northern Switzerland comprise two distinct complex sedimentary sequences differentiated by their topographical positions. The younger TDS complex includes deposits of at least four glaciations among which two are archived by till (Graf 2009 and references therein). The only evidence for the time of TDS deposition is indicated by an inverse magnetization, which may be correlated to the Matuyama Epoch, recorded in the TDS deposits in the Allschwil Brickyard near Basel (Forster and Schlüchter unpublished data; Kuhlemann and Rahn 2013). Therefore, the timing of TDS glaciations is still to be constrained. The older HDS complex also bears clear evidence for at least two glaciations that reached the northern Alpine Foreland during the Early Pleistocene (Graf 2009 and references therein). The HDS deposits indicate a time of accumulation in the foreland and may be evidence for first build-up of the Alpine ice sheet, which was capable to transport sediments from the high catchment areas down to the foreland. This accumulation period was interrupted by a period of incision, which created space for the deposits of the next accumulation phase, i.e., the TDS deposits (Fig. 1).

Based on our results from the stratigraphically youngest HDS deposits in MND, we conclude that the HDS glaciations terminated at the latest $1,020_{-120}^{+80} \mathrm{ka}$ ago. As a consequence, $1,020_{-120}^{+80} \mathrm{ka}$ is an upper bound for the beginning of the next incision phase, which may be correlated with the beginning of the global Mid-Pleistocene Revolution (MPR; e.g., Maslin and Ridgwell 2005). The MPR is the transition between 41 and $100 \mathrm{ka}$ glacialinterglacial cycles from low-amplitude/high-frequency to high-amplitude/low-frequency glacio-eustatic oscillations started by a first "100 ka-like" cycle between MIS (Marine Isotope Stage) 23 and 22 at around $950 \mathrm{ka}$ (Berger et al. 1993; Maslin and Ridgwell 2005; Fig. 8). The next cycle came immediately after this first phase of transition between MIS 21 and 20 at around $860 \mathrm{ka}$. This transition is then completed by a period of obliquity-dominated cycles between MIS 19 and 16, and 780 and $620 \mathrm{ka}$ (Maslin and Ridgwell 2005). The MPR is also recorded by the major change in the nannofossil assemblages in the North Atlantic between 900 and $860 \mathrm{ka}$ (Marino et al. 2011).

In the Alps, the MPR is attributed to re-organization of the drainage system of the Rhine and/or tectonics (Schlüchter 1981). In the northern Alps, Häuselmann et al. (2007b) applied the burial dating technique to cave sediments in the Siebenhengste cave system, canton Berne. 


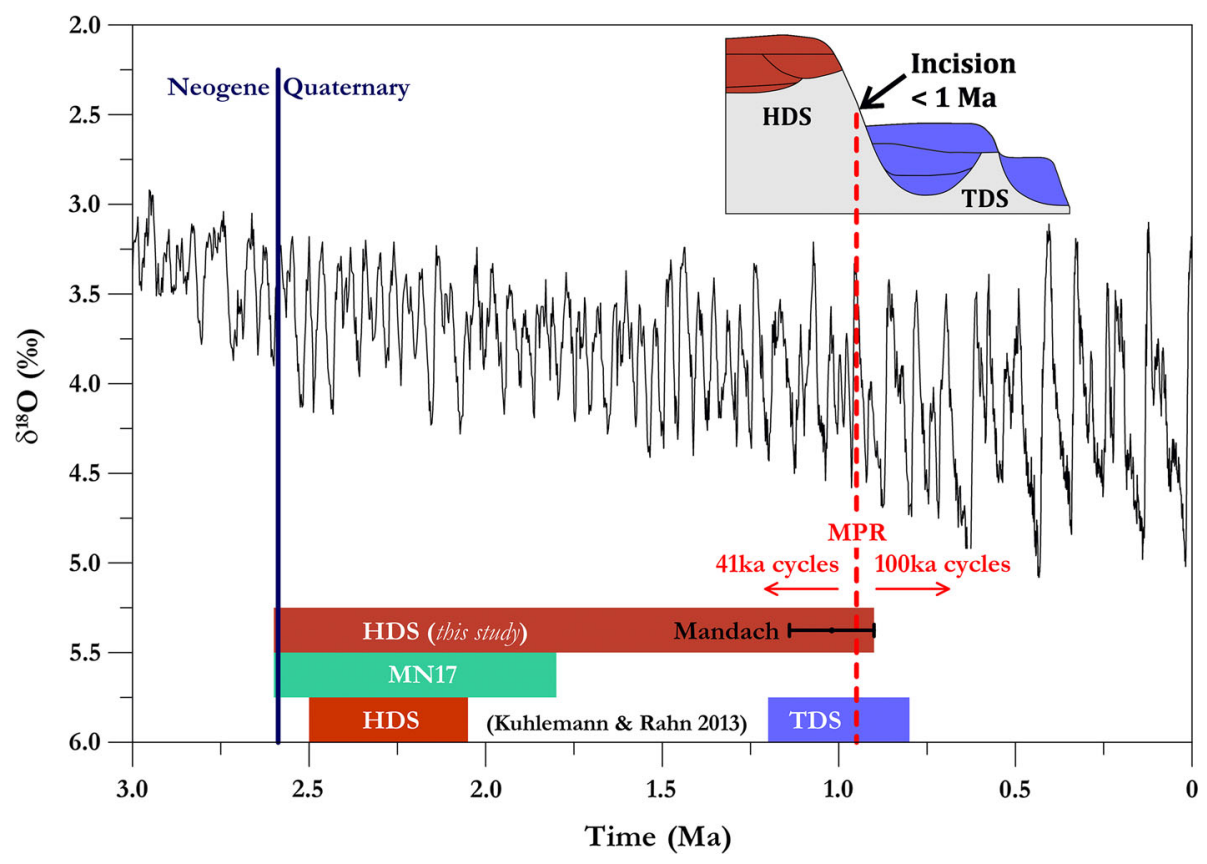

Fig. 8 The variation of global marine oxygen isotope during the last $3 \mathrm{Ma}$ (modified after Lisiecki and Raymo 2005) plotted against the present knowledge on Deckenschotter chronology. HDS (this study) is shown between the upper limit of Neogene Mammal Zone 17 (after Bolliger et al. 1996) and 1,020 $0_{-120}^{+80} \mathrm{Ma}$ (exposure age from the base of HDS) and it does not indicate continuous sedimentation. Tentative

Burial ages vary from $0.14 \pm 0.15$ to $4.35 \pm 0.60 \mathrm{Ma}$, except for the surface sample which yields a burial age of $0.07 \pm 0.19 \mathrm{Ma}$. They concluded that incision rates increased by a factor of ten at around 0.8-1.0 Ma, which may be related to the end of the HDS-related glaciations. In the southern part of the Alps, Muttoni et al. (2003) identified the evidence of a major glaciation during MIS 22 at $0.87 \mathrm{Ma}$. This is indicated by a sequence of periglacial braidplain facies and may be southern evidence for the Deckenschotter glaciations.

The end of the HDS-related glaciations at around $1 \mathrm{Ma}$ pre-dates the incision, which created accommodation space for aggradation during the TDS-related glaciations (Fig. 8). Our depth-profile age on the youngest HDS unit is the first chronostratigraphic value for Deckenschotter glaciations. This age also is coincident with the onset of the MPR. In addition, it allows an interpretation of a maximum erosion rate for post-HDS times. Assuming maximum incision of $110 \mathrm{~m}$ into bedrock and $100 \mathrm{~m}$ into HDS (after Graf 1993), respectively, we estimate a maximum erosion rate of around $0.1 \mathrm{~mm} / \mathrm{a}$ for both. This estimate is similar to the upper bound erosion rates reported by Kuhlemann and Rahn (2013). However, one should remember that this value would be a net average erosion rate, which also includes tectonic movements (uplift and/or subsidence), over the time period since the end of the Early Pleistocene. timings of HDS and TDS are drawn after Kuhlemann and Rahn (2013). The Mid-Pleistocene Revolution and the beginning of the transition between 41 and $100 \mathrm{ka}$ cycles are indicated at $0.95 \mathrm{Ma}$ (Maslin and Ridgwell 2005). The Neogene-Quaternary boundary is after Gibbard et al. (2010)

We think that it is too early for reasonable erosion rate estimation, and more chronological constraints are needed. For this reason, we do not discuss the implications of our results on incision and/or erosion rates. Also, the simulation code uses a "net erosion constraint" to calculate the exposure age (Hidy et al. 2010), such simulated erosion rate statistics cannot, and should not, be used to report erosion rates (viz. values presented in Table 3). This means that the code calculates a net thickness of sediment cover that was removed during the exposure, which is reasonable since erosion is certainly not constant over Ma time scales. Erosion has also two end members: gradual and instantaneous removal. Thus, the real erosion rate would vary between these two end members and the effect of uplift should also be incorporated. In that case, it is wise to use a "net erosion rate", which represents the total thickness of the sediment eroded during the time of exposure.

\section{Conclusions}

The chronology of the Swiss Deckenschotter, the oldest Quaternary units in the northern Alpine Foreland, is of both scientific and social importance. We collected 8 samples from two HDS sites, MND and IRC (type locality), for exposure dating with cosmogenic ${ }^{10} \mathrm{Be}$ depth-profiles. In 
order to calculate an exposure age, we used the Monte Carlo simulation code introduced by Hidy et al. (2010). We were not able to calculate an exposure age for the HDS at IRC, however the measured higher concentrations compared to the HDS at MND indicate a longer time of exposure at IRC. The depth profile simulation of the ${ }^{10} \mathrm{Be}$ concentrations from the MND samples yielded an exposure age of $1,020_{-120}^{+80} \mathrm{ka}$. Consequently, this exposure age is the first quantitative age for the Swiss Deckenschotter and it dates the end of HDS-related glaciations in the Swiss Alps. The cessation of HDS deposition apparently coincides with the beginning of the MPR, which was the change in the style of glaciation and landscape evolution. Our results from this study are consistent with the global evidence and directly contribute to our understanding of landscape change during the Early Pleistocene. Results from this study are encouraging and provide a motivation for new sampling campaigns, which would be a direct input for research on both Quaternary paleoclimate and environmental safety of radioactive waste repositories. We are fully aware of the fact that the data discussed here are a step towards solving problems and more substantial steps are necessary.

Acknowledgments We would like to thank Esther Haudenschild, Regina Reber and Dmitry Tikhomirov, at the University of Bern, for their help during the sample preparation. We would also like to thank the Laboratory of Ion Beam Physics accelerator mass spectrometry facility operated by the Swiss Federal Institute of Technology, Zurich, Switzerland. The quality of the paper has benefited from constructive anonymous reviews, which are especially acknowledged. This study was funded by the Swiss National Science Foundation (Project Nos. 200020-118038 and 200020-111878), the Surface Exposure Dating Laboratory at the University of Bern and the Swiss Federal Nuclear Safety Inspectorate (ENSI).

\section{References}

Akçar, N. (2006). Paleoglacial records from the Black Sea Area of Turkey: Field and dating evidence (p. 187). Ph.D. dissertation, University of Bern, Bern, Switzerland.

Akçar, N., Deline, P., Ivy-Ochs, S., Alfimov, V., Hajdas, I., Kubik, P. W., et al. (2012). The 1717 AD rock avalanche deposits in the upper Ferret Valley (Italy): A dating approach with cosmogenic ${ }^{10}$ Be. Journal of Quaternary Science, 27(4), 337-440.

Bailey, I., Hole, G. M., Foster, G. L., Wilson, P. A., Storey, C. D., Trueman, C. N., et al. (2013). An alternative suggestion for the Pliocene onset of major northern hemisphere glaciation based on the geochemical provenance of North Atlantic Ocean ice-rafted debris. Quaternary Science Reviews, 75, 181-194.

Balco, G., Briner, J., Finkel, R. C., Rayburn, J. A., Ridge, J. C., \& Schaefer, J. M. (2009). Regional beryllium-10 production rate calibration for late-glacial northeastern North America. Quaternary Geochronology, 4, 93-107.

Balco, G., \& Rovey, C. W. (2008). An isochron method for cosmogenic-nuclide dating of burried soils and sediments. American Journal of Science, 308, 1083-1114.

Balco, G., Stone, J. O., Lifton, N. A., \& Dunai, T. J. (2008). A complete and easily accessible means of calculating surface exposure ages or erosion rates from $\mathrm{Be}-10$ and $\mathrm{Al}-26$ measurements. Quaternary Geochronology, 3, 174-195.

Barendregt, R. W., \& Irving, E. (1998). Changes in the extent of North American ice sheets during the late Cenozoic. Canadian Journal of Earth Sciences, 35, 504-509.

Berger, W. H., Bickert, T., Schmidt, H., \& Wefer, G. (1993). Quaternary oxygen record of pelagic foraminifers: Site 806, Ontong Java Plateau. Ocean Drilling Program, Scientific Results, 130, 381-395.

Bini, A., Buonchristiani, J.-F., Couterand, S., Ellwanger, D., Felber, M., Florineth, D., et al. (2009). Die Schweiz während des letzteiszeitlichen Maximums (LGM), 1:500 000. Wabern, Switzerland: Bundesamt für Landestopographie, swisstopo.

Bolliger, T., Fejfar, O., Graf, H. R., \& Kälin, D. (1996). Vorläufige Mitteilung über Funde von pliozänen Kleinsäugern aus den höheren Deckenschottern. Eclogae Geologicae Helvetiae, 89, 1043-1048.

Chmeleff, J., von Blanckenburg, F., Kossert, K., \& Jakob, D. (2010). Determination of the Be-10 half-life by multicollector ICP-MS and liquid scintillation counting. Nuclear Instruments and Methods in Physics, Research Section B: Beam Interactions with Materials and Atoms, 268, 192-199.

Dehnert, A., Preusser, F., Kramers, J. D., Akçar, N., Kubik, P. W., Reber, R., \& Schlüchter, C. (2010). A multi-dating approach applied to proglacial sediments attributed to the most extensive glaciation of the Swiss Alps. Boreas, 39, 620-632.

Dunne, J., Elmore, D., \& Muzikar, P. (1999). Scaling factors for the rates of production of cosmogenic nuclides for geometric shielding and attenuation at depth on sloped surfaces. Geomorphology, 27, 3-11.

Ellwanger, D., Wielandt-Schuster, U., Franz, M., \& Simon, T. (2011). The Quaternary of the southwest German Alpine Foreland (Bodensee-Oberschwaben, Baden-Württemberg, Southwest Germany). Quaternary Science Journal, 60, 306-328.

Erlanger, E. D., Granger, D. E., \& Gibbon, R. J. (2012). Rock uplift rates in South Africa from isochron burial dating of fluvial and marine terraces. Geology, 40, 1019-1022.

Gibbard, P. L., Head, M. J., \& Walkers, M. J. C. (2010). Formal ratification of the Quaternary System/Period and the Pleistocene Series/Epoch with a base at $2.58 \mathrm{Ma}$. Journal of Quaternary Science, 25, 96-102.

Graf, H. R. (1993). Die Deckenschotter der zentralen Nordschweiz (p. 187). Ph.D. dissertation, ETH Zurich, Zurich, Switzerland.

Graf, H. R. (2000). Quartärgeologie zwischen Rhein, Thur und Aare (Kantone Aargau, Zürich, Schaffhausen; Exkursion G am 28. April 2000). Jahresberichte und Mitteilungen des oberrheinischen geologischen Vereins, 82, 113-129.

Graf, H. R. (2009). Stratigraphie von Mittel- und Spätpleistozän in der Nordschweiz. Beiträge zur geologischen Karte der Schweiz (Vol. 168). Wabern, Switzerland: Bundesamt für Landestopographie, swisstopo.

Graf, H. R., \& Müller, B. (1999). Das Quartär: Die Epoche der Eiszeiten. In: T. Bolliger (Ed.), Geologie des Kantons Zürich (pp. 71-95). Thun: Ott Verlag.

Granger, D. E., \& Muzikar, P. F. (2001). Dating sediment burial with in situ-produced cosmogenic nuclides: Theory, techniques, and limitations. Earth and Planetary Science Letters, 188, 269-281.

Gutzwiller, A. (1894). Die Diluvialbildungen der Umgebung von Basel. Verhandlungen naturforschende Gesellschaft Basel, 10, 576-587.

Häuselmann, P., Fiebig, M., Kubik, P. W., \& Adrian, H. (2007a). A first attempt to date the original "Deckenschotter" of Penck and Brückner with cosmogenic nuclides. Quaternary International, 164-165, 33-42.

Häuselmann, P., Granger, D. E., Jeannin, P. Y., \& Lauritzen, S. E. (2007b). Abrupt glacial valley incision at $0.8 \mathrm{Ma}$ dated from cave deposits in Switzerland. Geology, 35, 143-146. 
Hidy, A. J., Gosse, J. C., Pederson, J. L., Mattern, J. P., Finkel, R. C. (2010). A geologically constrained Monte Carlo approach to modeling exposure ages from profiles of cosmogenic nuclides: An example from Lees Ferry, Arizona. Geochemistry Geophysics, Geosystems, 11. doi:10.1029/2010GC003084.

Ivy-Ochs, S., Kerschner, H., Reuther, A., Preusser, F., Heine, K., Maisch, M., et al. (2008). Chronology of the last glacial cycle in the European Alps. Journal of Quaternary Science, 23, 559-573.

Jayet, A. (1949). Découverte d'une faunule malacologique de la fin du Pleistocène au contact de gravier günziens à Boppelsen (canton de Zurich). Eclogae Geologicae Helvetiae, 42, 436-441.

Kent, D., Opdyke, N. D., \& Ewing, M. (1971). Climate change in North Pacific using ice-rafted detritus as a climatic indicator. Geological Society of America Bulletin, 82, 2741-2754.

Korschinek, G., Bergmaier, A., Faestermann, T., Gerstmann, U. C., Knie, K., Rugel, G., et al. (2010). A new value for the half-life of Be-10 by heavy-ion elastic recoil detection and liquid scintillation counting. Nuclear Instruments and Methods in Physics, Research Section B: Beam Interactions with Materials and Atoms, 268, 187-191.

Kubik, P. W., \& Christl, M. (2010). 10Be and 26Al measurements at the Zurich $6 \mathrm{MV}$ Tandem AMS facility. Nuclear Instruments and Methods in Physics, Research Section B: Beam Interactions with Materials and Atoms, 268, 880-883.

Kuhlemann, J., \& Rahn, M. (2013). Plio-Pleistocene landscape evolution in Northern Switzerland. Swiss Journal of Geosciences, 106, 451-467.

Lal, D. (1991). Cosmic-ray labeling of erosion surfaces-In situ nuclide production-rates and erosion models. Earth and Planetary Science Letters, 104, 424-439.

Lisiecki, L. E., \& Raymo, M. E. (2005). A Pliocene-Pleistocene stack of 57 globally distributed benthic delta O-18 records. Paleoceanography, 20. doi:10.1029/2005pa001164.
Marino, M., Maiorano, P., \& Flower, B. P. (2011). Calcareous nannofossil changes during the Mid-Pleistocene revolution: Paleoecologic and paleoceanographic evidence from North Atlantic Site 980/981. Palaeogeography, Palaeoclimatology, Palaeoecology, 306, 58-69.

Maslin, M. A., \& Ridgwell, A. J. (2005). Mid-Pleistocene revolution and the 'eccentricity myth'. Geological Society Special Publications, 247, 19-34.

Muttoni, G., Carcano, C., Garzanti, E., Ghielmi, M., Piccin, A., Pini, R., et al. (2003). Onset of major Pleistocene glaciations in the Alps. Geology, 31, 989-992.

Penck, A., \& Brückner, E. (1909). Die Alpen im Eiszeitalter (p. 364). Leipzig: H. Tauchnitz.

Preusser, F., Graf, H. R., Keller, O., Krayss, E., \& Schlüchter, C. (2011). Quaternary glaciation history of northern Switzerland. Quaternary Science Journal, 60, 282-305.

Schlüchter, C. (1981). Remarks on the Pleistocene morphogenetic evolution of the Swiss Plain. Zeitschrift für Geomorphologie, N.F. Suppl.-Bd., 40, 61-66.

Schlüchter, C. (1988). The deglaciation of the Swiss Alps: A paleoclimatic event with chronological problems. Bulletin de l'Association Française pour l'étude du Quarternaire, 2(3), 141-145.

Sejrup, H. P., Larsen, E., Haflidason, H., Berstad, I. M., Hjelstuen, B. O., Jonsdottir, H. E., et al. (2003). Configuration, history and impact of the Norwegian Channel Ice Stream. Boreas, 32, $18-36$.

Stone, J. O. (2000). Air pressure and cosmogenic isotope production. Journal of Geophysical Research, 105(B10), 23753-23759.

Walker, M. J. C. (2005). Quaternary dating methods (p. 304). Chichester: Wiley. 